\title{
Panentheism and Panexperientialism for Open and Relational Theology
}

\author{
Thomas Jay Oord and Wm. Andrew Schwartz
}

Open and relational theologies have a particular affinity for panentheism and panexperientialism (panpsychism). These theologies come in various forms, however. And scholars propose various forms of panentheism and panexperientialism. Diversity reigns.

We begin this essay by describing open and relational theology. We also describe panentheism and panexperientialism, broadly understood. We note reasons why open and relational theists would be attracted to each. And we argue that panentheism and panexperientialism complement one another, although a person could be attracted only to one.

Much of the essay argues for one form of open and relational theology we think makes the best sense overall. This form includes belief in a personal/ relational God, makes distinctions between God and creatures, affirms God everlastingly creates (thereby denying creatio ex nihilo), and offers a solution to the theoretical aspect of the problem of evil. Adopting panexperientialism and panentheism offers ways to overcome theoretical problems in contemporary thought, while arguably motivating adherents of the view to love (promote overall well-being).

\section{Open and Relational Theology}

The label »open and relational theology« serves as an umbrella designation for a family of theologies. ${ }^{1}$ This family shares at least two core convictions. The »open « aspect refers to the idea that both creatures and God experience the ongoingness of time. Consequently, both God and creatures face an open, yet to be determined future. Because the future is not actual, it is inherently

1 These include theologies using labels such as open theism, process theism, various relational theologies, some Wesleyan theologies, some feminist theologies, some ecological theologies, some Arminian theologies, some postcolonial theologies, and more. Thomas Jay Oord coined the »open and relational theologies « label in 2001 when forming a group that meets annually at American Academy of Religion (AAR) meetings. Andrew Schwartz currently serves as the group's chair. 
unknowable as actual. Open and relational theists believe God is time-full rather than timeless. ${ }^{2}$ Theistic presentists often adopt this view of divine time-fullness.

The open view is perhaps best known for rejecting the traditional view of exhaustive divine foreknowledge. That traditional view says God knows with certainty what happened in the past and present, and God foreknows the future with certainty. Open theism rejects the portion of that view that says God foreknows the actual future with certainty. Most open theists maintain God is omniscient, however, because God knows all actual and potential events and beings. God knows everything knowable.

The »relational« aspect of these theologies refers to the give-and-receive interactions that characterize all existence. Creatures and other elements of creation relate with one another, in this sense of being causally influencing. God also engages in give-and-receive relations with others. Open and relational theists reject classic theistic views of divine impassibility and immutability, which say God in all respects remains unaffected by creation and unchanging. Relational theists believe God relates experientially with creatures.

Open and relational theists typically embrace a set of other ideas. Most emphasize love as God's primary attribute and the moral imperative for at least complex creatures. ${ }^{3}$ Most affirm some form of libertarian freedom, at least for God and complex creatures. ${ }^{4}$ This freedom is genuine but limited by the capacities of the agents and the influences in their environments. Most open and relational theists affirm some version of epistemological realism, whereby reality actually exists prior to one's perception of it. This realism means, among other things, we can know something but not everything about God and the world. ${ }^{5}$ Open and relational theologians affirm differences and similarities between God and creation. Most believe creation matters, and what we do makes an ultimate difference. And so on.

Self-identified open and relational theists disagree among themselves on issues other than the ideas we have noted. Some reject creatio ex nihilo, for instance, while others affirm it. ${ }^{6}$ Some affirm the salvation of nonhuman

2 For arguments on God as »time-full, « see Oord $2010 a$.

3 See Wynkoop 1972.

4 See Pinnock 2005.

5 When we speak of the »world « as that which God relates, we mean the cosmos most broadly (i.e. reality) and do not intend to restrict this relation to planet Earth and its residentsalthough Earth and its inhabitants are certainly part of this broader cosmos. The same is true when we refer to »creation.«

6 See Thomas Jay Oord, ed. Theologies of Creation: Creatio Ex Nihilo and its New Rivals (New York: Routledge, 2019). 
creatures, but others do not. Some stress the importance of traditional views of Trinity; others seek novel Trinitarian formulations; still others eschew Trinitarian ideas. Some place special emphasis upon the Bible as their primary source for knowledge of God, others emphasize the Bible less.

We see this diversity as a strength. Open and relational theologies avoid rigidity. Most in this tradition try to be humble in their claims about what we can know, even the core views of open and relational theology. But being humble is compatible with working boldly to make better sense of reality by speculating about God, creation, values, causation, relations, ethics, beauty, and more.

Given these general characteristics of open and relational theologies, we turn to two topics on which open and relational theologians differ among themselves: panentheism and panexperientialism.

\section{God and the World: Panentheism}

Many open and relational theists are attracted to panentheism. In fact, prominent supporters of panentheism in the past and present fit comfortably under the open and relational label. ${ }^{7}$

Panentheism's defining insight is that »all is in God. « This brief phrase has been interpreted in various ways. ${ }^{8}$ Thomas Jay Oord identifies more than a dozen interpretations of what »in " means to self-identifying panentheists. Some versions of panentheism are spatial, for instance, others comparative, some metaphorical, and still others causal. This diversity indicates a lack of clarity, but a measure of imprecision and disagreement are understandable given the subjects in question: God and everything else! ${ }^{9}$

7 Among the many examples that could be listed, we note especially Ian Barbour, Bradley Artson, Joseph Bracken, Philip Clayton, John Cobb, Carol Christ, John Culp, Roland Faber, Matthew Fox, Benedikt Göcke, Neils Gregersen, David Ray Griffin, Charles Hartshorne, Nancy Howell, Catherine Keller, Michael Lodahl, Jay McDaniel, Sallie McFague, Jürgen Moltmann, Thomas Jay Oord, Arthur Peacocke, Wm. Andrew Schwartz, Marjorie Suchocki, Donald Wayne Viney, Keith Ward, Michel Weber, Kirk Wegter-McNelly, Alfred North Whitehead, and Anna Case Winters.

8 For an example of this variety of panentheism meanings, see Clayton and Peacocke 2004. See also Barbour 1990, Cooper 2006, Gocke 2013, Jantzen 1984, Peacocke 1979 and 2004, Peterson 2001, and Ward 2007.

9 See Oord's comments in In Whom We Live and Move and Have our Being: Panentheistic Reflections on God's Presence in a Scientific World (Oord 2004). R.T. Mullins also addresses the problem of various definitions in »The Difficulty with Demarcating Panentheism« (Mullins 2016). 
We think panentheism, at a minimum, says creation is in God's all-embracing, moment-by-moment experience. Being in God's experience implies that God is experiential and affected by creaturely others. God is passible. Panentheism differs from theologies of passibility that claim only humans or complex creatures affect God's experience. It says all actual entities affect God's passible experience. Although saying creatures affect God does not require believing deity is personal, most open and relational theists think of God this way. ${ }^{10}$

Saying creation affects God directly opposes the classic views of divine impassibility and immutability. Theologians like Augustine, Thomas Aquinas, and John Calvin thought God was unaffected and unchanging in all respects. To them, this is the essence of divine perfection. Augustine explains it this way, »There is no modification in God, because there is nothing in him that can be changed or lost ... he remains absolutely unchangeable. «11 Carl F.H. Henry states the view succinctly: God is perfect and, if imperfect, can only change for the worse. «12

The 2oth century's leading proponent of panentheism, Charles Hartshorne, believed classical theism was partly right. God's essence is perfectly unchanging and unaffected. But a fuller sense of divine perfection adds that God's experience perfectly changes because God is affected by creation..$^{13}$ Nearly all open and relational theists agree with Hartshorne. Some use the label »dipolar « theism to describe this. Thomas Jay Oord calls it God's »essence-experience binate. «14

Open and relational thinkers point to God's steadfast but relational love to illustrate this double perfection. God's love is steadfast in the divine essence, because God consistently loves creation. This never changes. But insofar as love involves giving and receiving, God's loving experience changes in dynamic relationship with creation. God is the »most moved mover, « to use Abraham Heschel and Clark Pinnock's description of divine passibility. ${ }^{15}$

The Psalmist points to both forms of perfection: God »repents according to the abundance of his steadfast love« (Ps. 106:45). To »repent« means to change;

10 As will be explored more fully below, consciousness and personhood is not a prerequisite for »experience« as outlined by Griffin and other panexperientialists.

11 Augustine 2012.

12 Henry 1982: 304. For another who endorses the argument that God cannot change in any sense, see Charnock 2015.

13 Hartshorne 1984: 2.

14 Many process-oriented theists prefer the »dipolar theism« label. Charles Hartshorne raised the label to prominence. For instance, see his essay »The Dipolar Conception of Deity« (Hartshorne 1967) and Viney 2007.

15 Pinnock: 2001. 
»steadfast « means to change not. God's love involves both forms of perfection: perfect flexibility and perfect stability. ${ }^{16}$

\section{Immanence and Transcendence}

Advocates and opponents of panentheism use the labels »immanence « and »transcendence« to portray God and creation. Diversity reigns in the use and meanings of these words, however, so confusions abound.

Most open and relational theologians stress God's nearness. God is with us. When immanence and transcendence are understood spatially, panentheism affirms divine immanence: God is present to all creation. But the spatial meaning of panentheism is controversial. Opponents of panentheism also believe an omnipresent God is near to all. Despite the ambiguity, many advocates of panentheism emphasize this view of immanence as motivating their preference for this view of the God-world relationships. ${ }^{17}$

The spatial distinction sometimes relies upon the mode of God's knowing creation. Theologians who affirm God's impassibility in all respects often say God knows creation by »seeing « it. »The eyes of the Lord are on all creation« (Prov. 15:3). This metaphor implies a distance between the seer and the objects seen. By contrast, open and relational theologies often stress God's »feeling « or »relating with « all creation. God »is not far from each one of us; for in [God] we live and move and have our being " (Acts 17:27-28). Experiential knowledge implies God's near and direct presence.

Theologians sometimes use immanence and transcendence language to describe God's relation to time. If immanence points to God »in« time (pantemporal) and transcendence to God »outside« time (nontemporal), open and relational thinkers opt for God's experience as immanent. God experiences the unfolding of reality in sequential moments, analogous to how creatures experience it. Open and relational theologians affirm, however, that God transcends creatures by existing everlastingly.

The version of panentheism we embrace also says that God is aware, purposive, responsive, and partly free. These elements support the view God is a person or personal, although many open and relational theologians prefer to say God is »relational.« Unfortunately, »personal« connotes the notion of a localized body (»see that person over there?«) or preferential treatment (»why

16 See especially Oord 2010: chs. $3-5$.

17 For instance, see Davis and Clayton 2018. 
does she get a personal trainer?«). We think God is an incorporeal, omnipresent Spirit who loves all creation without playing favorites. ${ }^{18}$

Open and relational thinkers differ among themselves on whether God necessarily or contingently experiences creation. Those who say God's relations with the world are metaphysically contingent typically believe God once existed alone and decided to create the universe out of nothing (ex nihilo). God's relationality with creation is contingent on God choosing to create and be in relation with creaturely others. In this view, primacy is given to God's freedom from creation. Insofar as an act of love is free, some argue, God must be free to love or not love. Many in this group think God essentially relates within Trinity and contingently relates to creation. ${ }^{19}$

Open and relational thinkers who say God necessarily relates with creatures typically believe God has always been creating and relating with creaturely others. They deny God once existed alone and decided to create from absolute nothingness. On this second view, God essentially loves and relates to creation. A few in this group believe God essentially relates both with creation and in Trinity, making God doubly essentially related and loving. ${ }^{20}$ God is not free whether to love creaturely others, because God's nature requires such love. But God is free to decide how to love creaturely others.

Despite these variations, open and relational theists typically agree with Charles Hartshorne when he says, »The primacy of love means that there is no possible value that any being could have simply in and by itself, or simply by its own decision. ${ }^{21}$ In other words, love is necessarily relational, whether between creatures, between God and creatures, and/or within the Triune self.

\section{Theocosmocentrism}

We find most plausible the form of panentheism that says God necessarily or essentially relates to creation. To distinguish our view from other forms, we call it »theocosmocentrism. « As we define it, this view affirms an epistemological

\footnotetext{
18 Open and relational theologians in the Latter-day Saints (Mormon) tradition believe God has a localized body. We do not follow this tradition, opting for the more widely embraced view that God is an incorporeal spirit (pneuma or ruach).

19 For example, see Bracken 2004, and Clayton 2005.

20 Thomas Jay Oord explores doubly necessary divine relations in The Nature of Love. (Oord 2010a) For an argument focused on Jesus as the key insight for such double necessity, see Moltmann 1993.

21 Hartshorne, 1984.
} 
commitment that both God (theo) and creation (cosmos) are central to understanding reality.

Most theists deny that anyone can offer an overall adequate explanation of creation without reference to God. Theocosmocentrism agrees. But it adds that one also cannot offer an overall adequate explanation of God without reference to creation. We cannot know God well without God's revelation in the world. While God comes logically first and is not co-equal with creation, both the Creator and creatures play necessary roles in understanding existence. This view plays an important role in how one thinks about issues in the scienceand-theology dialogue.

The epistemological commitment of theocosmocentrism entails ontological commitments as well. This view of panentheism says God necessarily loves and relates to creation. Unlike forms of panentheism that say God's love for creation is contingent or arbitrary, theocosmocentrism says God's love for creation is an essential aspect of God's eternal nature. »God is love, « from this perspective, means God essentially loves ad extra and not merely ad intra. And this is necessarily so everlastingly.

From the perspective of theocosmocentrism, the view that God once existed alone and then created from nothing (creatio ex nihilo) has numerous liabilities. We propose a doctrine of initial creation that says God always creates out of that which God previously created. God everlastingly creates. We might call the view creatio ex creatione sempiternaliter en amore (God creates out of creation everlastingly in love) if we want the Latin. God is ever Creator, not the at-one-time-started-to-create Creator.

Attributing necessarily divine properties is common (if not logically necessary) for Christian theologians. The idea God everlastingly creates says creating is an essential attribute for God. We resist the label »infinite regress « to describe our view, however. »Infinite « says nothing positive; it simply says »not finite. « We prefer »everlastingly« to describe a beginningless and unending sequence of God's creating activity. ${ }^{22}$ »Regress « suggests backward causation, which we reject. We argue time necessarily flows forward, so creating is always progressive.

Rejecting creatio ex nihilo allows one to reject the problematic view of divine power implied in it. The God who creates from nothing is ultimately responsible for setting up all cosmological laws of existence, deciding them by fiat. This God could break those laws on occasion to prevent evil. The ex nihilo Creator could make something new in the present from nothing instantaneously to stop evil. A God with that kind of power is culpable for failing to prevent the

22 For further analysis of divine infinity see, Göcke and Tapp (eds.) 2018. 
genuine evil we see in our lives, and therefore that God does not consistently love. To put it differently, because genuine evils occur that a loving God with creatio ex nihilo power ought to prevent, we reject God has ever or even could create ex nihilo. We also have biblical, ecological, conceptual, revelational, and scientific reasons to reject creation from nothing. ${ }^{23}$

Theocosmocentrism rejects traditional views of divine power that say God does or could unilaterally determine creatures or situations. Instead of conceiving of God's power in terms of singlehanded coercion, this form of panentheism conceives of God's power as persuasive, relational, and inviting. C. Robert Mesle describes this nicely: „God's power is the power that enables all of reality to continue its creative advance that makes creatures free, that shares the experience of every creature and is experienced by every creature. $\ll^{24}$

Thomas Jay Oord argues for an »essential kenosis« view of divine power. This view says God's love is kenotic, in the sense of self-giving and othersempowering. Love so conceived comes logically first in God's nature, prior to the divine will. This means God is essentially self-giving and others empowering, and God could not choose to be otherwise. Out of love, God must therefore give freedom, agency, self-organization, or existence to creatures (depending on their complexity). God cannot withdraw, override, or fail to provide creatures or creation these capacities. In sum, God's love makes God incapable of controlling others. Among other advantages, essential kenosis solves the central conceptual question in the problem of evil: God does not have the power to prevent evil singlehandedly.

Theocosmocentrism says God essentially relates to creation. This is meant in two distinct but complementary ways. First, insofar as God's nature is love and love requires relations with others, God necessarily relates with others. These »others« at least include creation if not also relations within Trinity.

Second, theocosmocentrism says existence is constituted by relations. In so far as the structure of existence is relational, God-like all existing beings-is necessarily relational. While the Creator differs from creatures in many ways, the meaning of »relates with « applies to both. Just as there was no absolute beginning to God's creative activity, God has also always been relating to all

23 A brief explanation: the Bible doesn't explicitly reveal creatio ex nihilo, it's hard to be motivated to save ecosystems or the planet from collapse if God can create another universe ex nihilo, we know of no empirical examples of ex nihilo and the ancient phrase seems to ex nihilo nihil fit apply, the God with ex nihilo power is capable of providing and preserving inerrant revelation, and the amount of dark energy and dark matter in the universe is apparently inconsistent with big bang cosmologies tied to creatio ex nihilo.

Mesle 1993: 14 . 
others: past creation, present creation, Godself, and future creation when it comes into being.

\section{Ontological Distinctions between God and Creation}

Critics sometimes accuse forms of panentheism of failing to distinguish God's ontology from creation's. ${ }^{25}$ Because of their emphasis upon divine immanence, panentheists are sometimes charged with anthropomorphism. Such criticisms apply to some forms of panentheism but not all. Theocosmocentrism makes careful ontological distinctions between the Creator and creation.

Theocosmocentrism describes a God who transcends creatures in many ways. For instance, it says God is everlasting: God had no beginning and will have no end. By contrast, all creatures, worlds, or universes have beginnings and ends. This form of panentheism says God is omnipresent, in the sense of being present to all creation. By contrast, creatures are localized. ${ }^{26}$ Theocosmocentrism says God is transcendent by existing necessarily; creatures exist contingently. ${ }^{27}$ It says God necessarily loves, although how God loves is freely contingent. Creatures capable of love must choose both whether and how to love. As noted above, theocosmocentrism affirms a form of transcendence most theologies do not: it says God everlastingly creates. Creatures temporarily create as created co-creators in response to God. ${ }^{28}$ Like most theologies, this form of panentheism affirms the transcendence of divine omniscience: God knows all that can be known. ${ }^{29}$ Creatures are not omniscient.

Theocosmocentrism says God is distinct numerically from any creature and creation as a whole. The being of God is not the being of creation; the world is not literally God's body. This numerical difference does not mean spatial

25 For instance, see Cooper 2006.

26 While the spatially location of creatures is distinctive, it's important to avoid thinking of this location in terms of atomicity, permanence, or individual independence. Doing so is to commit the fallacy of simple location, as Alfred North Whitehead called it.

27 To clarify, while particular creatures exist contingently, the notion of God as ever Creator implies that some non-particular creatures (abstractly) or another exist necessarily. Like a woman who exists everlastingly but is always married to temporarily existing men-each man being born and dying in succession-God exist everlastingly and creates and relates with contingent creatures-each being temporary.

28 Given that theocosmocentrism redefines God's power as relational (not unilateral), all acts of divine creation can be understood as acts inviting cooperative co-creation.

29 Particular creatures always »know « as particular creatures, always in a particular context from a particular perspective. Therefore, the epistemic limits to creaturely knowledge are tied to the ontological limits of creatures as embodied and spatially-temporally located. 
distance, as if God were watching creation from somewhere else. God is distinct from and not the same as creation, but God relates directly with creation. God necessarily exists $(a \mathrm{se})$ but necessarily relates to creation. This interdependent and essential relationality of God and the world is a unique marker of theocosmocentric panentheism.

God and creation share some similarities. Without such sharing, absolute apophatism would be true. Such similarities prompted Alfred North Whitehead to say God is »not an exception to the metaphysical principles« of reality. ${ }^{30}$ For instance, God and creatures are experiencing beings, and creation is comprised of experiencing entities. God and creatures perceive others, although as we will explain later, this perception is nonsensory. God and creatures both exert causal influence. The formal definition of love applies both to God and creatures capable of love, but there exist differences in degrees, expressions, and modalities. ${ }^{31}$

In sum, theocosmocentrism offers a matrix of claims about God's transcendence and immanence in relation to creation. ${ }^{32}$ The content of this matrix distinguishes it from other forms of panentheism. A full explication of this matrix extends beyond the constraints of this essay.

\section{The Experiencing Aspect of Panexperientialism}

Open and relational thinkers believe that at least complex creatures experience God. The most complex sometimes experience God with a measure of cognitive awareness. But open and relational thinkers differ among themselves

$30 \quad$ Whitehead 1978 (1929): 343 .

31 Some of the most systematic and comprehensive work on formal definitions of love can be found in Thomas Jay Oord's works, including Science of Love: The Wisdom of Well-Being (2004), The Nature of Love: A Theology (2010a) and Defining Love: A Philosophical, Scientific, and Theological Engagement (2010b). In Defining Love, Oord offers a formal definition of love, stating, »To love is to act intentionally, in sympathetic response to others (including God), to promote overall well-being « (15).

32 Roland Faber argues for an alternative view of panentheism worth particular note. To capture an often-overlooked nuance in Whitehead's views of the God-word relationship, Faber speaks of the notion of mutual immanence as mutual transcendence. He proposes a new term »transpantheism.« As Faber notes, God and the world »exceed one another, and only for that reason, can be seen by Whitehead to be mutual instruments of novelty for one another « (The Divine Manifold [2014] and The Becoming of God [2017]). Because we think God and creation are ontologically distinct in the sense of their not being identical (pantheism), we affirm that creation exists in different ways than God exists. Consequently, Faber's transpantheism is compatible with theocosmocentrism, and both are forms of panentheism. 
on the precise meaning of »experiencing.« They also differ on which creatures are capable of experiencing in general and experiencing God in particular. Some distinguish between humans and other creatures, others between animate and inanimate creation. Some believe experience is an emergent phenomenon arising at some time in the evolutionary process. ${ }^{33}$ Others believe all creatures and created entities - from the most complex to the simplestexperience others. We count ourselves in this last group.

The view that all existing entities experience is often called »panpsychism." The label is problematic, however, for several reasons. The »psych« in the panpsychism label might suggest all things - from quarks to rocks to cells to amoeba to elephants to galaxies-have conscious experiences. We reject that view.

The »panpsychism « label also highlights the mental dimensions of existing entities without reference to the physical dimension we think present in all existing entities. One might think panpsychism is a form of idealism saying ideas are the only real things in the universe or that physicality is ultimately an illusion. By contrast, we think actual things possess physical aspects.

We prefer the word David Ray Griffin coined: »panexperientialism. « All existing entities are experiencing entities. ${ }^{34}$ Panexperientialism, as we conceive it, says all creatures have both mental and physical dimensions..$^{35}$ Thomas Jay Oord calls this duality, »dual-aspect monism.« One of panexperientialism's great strengths is its ability to account for what's true about both physicalism and idealism, while overcoming the shortcomings of the reductionist forms of these metaphysical views.

Key to understanding dual-aspect monism is distinguishing between how the creatures and things of the world are organized internally. Charles Hartshorne referred to some creatures as »compound individuals« and other things as »aggregates « (or aggregational societies). ${ }^{36}$ With some exceptions, we might say existing things are organized as animate and inanimate. ${ }^{37}$

Animate creatures have some central entity around which the individuals and groups comprising those creatures organize. In humans, we call this

33 For example, see Clayton 2006.

34 Griffin first coined the term »panexperientialism, « in his article »Panexperientialist Physicalism and the Mind-Body Problem, « (1997).

35 We distinguish between »actual« entities and »real« entities. All actual entities are real, but not all real entities are actual. Real but not actual entities include the color blue, mathematical equations, and the (current) possibility that Andrew Schwartz will one day become president of the United States.

36 Hartshorne 1970: 90.

37 Some things in the world have both animate and inanimate dimensions. Plants are perhaps the best examples of these things. Other entities are real but don't actually exist. Possibilities are good examples of real but not actually existing entities. 
central member the mind. But in less complex creatures, the organizing entity might be far less complex. Examples of animate creatures include dolphins, dogs, mice, worms, and cells. But »even macromolecules, ordinary molecules, and atoms might be supposed to be compound individuals, « argues Griffin. ${ }^{38}$

Aggregates, by contrast, are inanimate. They have no central member and are therefore not organized as individuals. Consequently, inanimate objects cannot act or respond as a whole. Examples include buildings, chairs, rocks, plastic, and water. An inanimate object has no »overall experiential unity that allows it to feel and act as an individual, « explains Griffin. Because an inanimate object has no experiential unity, it has no power to respond to its environment as a unity. ${ }^{39}$ To put it differently, an inanimate entity cannot act qua inanimate entity, but its individual constituents do act.

The distinction between animate individuals and inanimate aggregates proves important for talking appropriately about diverse creatures and entities in creation. We rightly say mice respond to stimuli, for instance, but rocks don't. »Respond « implies a degree of unity, agency, and freedom, although it may be small. Mice have a central member around which much of their being organizes. The rock as a whole cannot respond. While the smallest entities that comprise a rock are themselves experiential, they are not organized around a central member. Consequently, humans, dolphins, dogs, mice, worms, cells, and molecules experience their environments and respond. But buildings, chairs, rocks, plastic, and water do not experience their environments and respond.

As implied in our reservations about the label »panpsychism, « we distinguish between mentality and conscious experiences. We use »mentality« in a very broad way, of which conscious mentality is a rare case. Only the most complex creatures enjoy conscious experiences. Simple but animate creatures and inanimate objects do not experience consciousness. ${ }^{40}$ The capacity for consciousness emerged in evolutionary history smoothly from less complex species with mentality but not consciousness. We call this »smooth emergence.«41

Complex creatures capable of conscious experience represent a miniscule percentage of entities known to exist. Conscious experience represents a minuscule percentage of the experiences of conscious beings. For example,

\footnotetext{
38 Griffin 1998: 186.

39 Griffin 1998: 186.

40 We prefer the term »non-conscious « to »sub-conscious, « because sub-conscious implies consciousness in a way that would either require assigning consciousness to entities like rocks, or denying that rocks have experiences. We believe the term non-conscious allows a way to speak of rock experiences without imply rock consciousness.

We are grateful to Joanna Leidenhag for suggesting this label in private conversations.
} 
humans are not conscious of the vast majority of their bodily experiences (from basic activities like breath to interactions on a cellular level). But they are conscious of some of their experiences.

\section{Duality without Dualism}

Understandably, many people want to avoid dualistic views that lead to insurmountable conceptual difficulties. To this point in the essay, we've explored ideas that speak of dual components. In this section, we explain that these ideas involve dualities. But they avoid insurmountable conceptual difficulties inherent in dualism. In fact, they overcome those dualisms.

One way to speak of dualities without dualism is to speak of distinctions without absolute separation. A coin, for instance, has both heads and tails. These are distinct but part of the same coin. If they weren't distinct, the coin toss at the Super Bowl's beginning would be useless.

Dualities as distinctions are present throughout reality. God and creation are distinct yet, according to theocosmocentrism, inseparable: duality without dualism. Panexperientialism says the physical and mental dimensions of all existing things are distinct but inseparable: dual-aspect monism. ${ }^{42}$

We addressed earlier problems that arise from an absolute God-world dualism that leads to apophatism. We believe that although God transcends creation in some respects, God and creatures share other respects. We also rejected the God-world dualism that says God's relations with creation are in all senses metaphysically contingent. We said God necessarily or essentially relates with creation. Rejecting creatio ex nihilo leads to affirming a necessary God-world duality too. And so on.

Understanding how our minds and bodies relate has been a central concern since at least the seventeenth century. The problem derives from commonsense experience. We naturally believe we have minds that experience the world. And we naturally believe our bodies influence our minds. But how can a purely mental and nonphysical thing — a mind —interact with purely physical and nonmental things - the constituents of our bodies?

Reductive physicalist views say existence is purely material/physical. If true, such physicalism allows no room for explaining our unity of experience, sense of freedom, values, and more. If humans are entirely comprised of physical entities with no mental dimensions, we have no way of explaining

42 Alfred North Whitehead describes actual entities as »dipolar, « consisting of both a physical and mental pole (Whitehead 1978[1929]: 239). 
unified conscious experience..$^{43}$ Sometimes referred to as the »hard problem of consciousness, «44 the challenge for physicalists is explaining the empirical data we know best: our conscious experiences.

Idealist views come in various forms, but some suggest reality consists entirely of mentality and ideas. If true, such idealism allows no room to explain how the apparently physical world outside our minds exerts physical influence. The world explored by science seems comprised of physical things independent of our minds. The challenge for at least some forms of idealism is explaining the physical world as actually physical and not our mental construct or simply ideas.

In response, many affirm a form of mind-body dualism we reject. This mind-body dualism says we have purely mental minds that interact with purely physical bodies and other entities in the world. How two entirely different things can be causally influential—what Jaegwon Kim calls »the combination problem ${ }^{45}$ — remains a mystery. Rene Descartes appealed to the pineal gland; others appeal to the unilateral action of God.

The dual-aspect monism of panexperientialism overcomes Cartesian mindbody dualism. It rejects the view that our minds are purely mental and our bodies and other entities purely physical. Dual-aspect monism affirms the duality of the physical and mental in each existing thing: our minds have both a mental and physical aspect, and every entity, cell, organ, and member of our bodies and other entities in the world have mental and physical aspects. ${ }^{46}$

In so far as dual-aspect monism attributes a physical dimension to the mind, it naturalizes it. ${ }^{47}$ In so far as dual-aspect monism attributes a mental dimension to all physical entities, it offers a robust form of non-reductive physicalism to account for mentality. In so far as dual-aspect monism is central to smooth emergence, it provides a conceptual account for the emergence of consciousness from less complex entities with an iota of mentality but not consciousness.

Panexperientialists often call their view »organismic. ${ }^{48}$ This word points to the relational, experiential, and vital aspects of the view. In biology, for

43 We would extend this to include other (non-human) conscious entities as well, though for dualists like Descartes, only humans are thought to have a »mind/soul.«

44 See Chalmers 1995.

45 Kim 2005.

46 While non-dualism is much more common in Eastern philosophy (e.g. Śankkara's Advaita Vedānta, Rāmānuja's Viśișțādvaita Vedānta), many Western philosophies have been nondual in orientation (e.g. most forms of Christian mysticism, Whitehead's philosophy of organism).

$47 \quad$ Griffin 1998: 78.

48 In Process and Reality, Alfred North Whitehead refers to his work as a "philosophy of organism.« 
instance, organisms are alive and dynamic, always adapting to their surroundings. In social terms, organisms are interdependent parts that make up a whole. In these cases and more, the language of organism connotes a sense of relational becoming, which appeals to open and relational thinkers.

Organismic views stand in contrast to mechanistic ones. Mechanistic views connote substantival, nonrelational, and nonexperiential ontologies. Unfortunately, much contemporary philosophy of science adopts the mechanistic worldview. Despite acting with purpose, feeling, and consciousness, many scientists assume the world and its creatures have no purpose, feeling, or mentality. The dual-aspect monism of panexperientialism overcomes this self-contradiction.

We readily admit that we cannot prove in a deductive way the truth of dualaspect monism or panexperientialism. We cannot deduce from first principles that experience-based and organismic ontologies are truer explanations of existence than substance-based and mechanistic ontologies. There is no proof that every existing individual and entity is or is not comprised of mentality and physicality. We do find advantages to panexperientialism, however, that combined with theocosmocentrism lead us to prefer it to alternatives.

\section{Some Advantages to Our Views}

Panexperientialism and theocosmocentrism account well for reality. We've already mentioned several advantages above. In this section, we list several more.

Ecological advantage: A growing number of people believe creatures great and small deserve respect and protection. This deserving is based not just on the value these creatures have for human flourishing. A growing number of people believe all creatures have value in and for themselves; they are intrinsically valuable. Recognizing the intrinsic value of creation initiates a fundamental shift from the commodification and exploitation of natural resources.

Panexperientialism provides a conceptual framework for affirming the sense that all creation and all creatures possess intrinsic value. Panexperientialism says not only that all creature's experience, but it also says all experiences are valuative. In so far as an entity is a subject, it feels values. In so far as an entity is an object, it offers values that others feel. Values are thus understood as intrinsic qualities of reality. Those who care about animals and the environment have panexperientialism as a conceptual ally.

Evolutionary consistency advantage: The evolutionary picture of reality says increasingly complex creatures emerged over long periods. This 
emergence was gradual; it occurred as the result of mutations, environmental factors, self-causation, and (in the opinion of theists) divine action. A puzzle arises, however: How can experiencing creatures like ourselves (and apparently other complex organisms) gain the ability to experience from nonexperiencing simpler entities? Some call this puzzle the »genetic problem« in evolution.

So-called »strong emergentists « claim that in some mysterious way, the conditions in and among species became complex enough for simple creatures to attain the ability to experience. This claim feels like a wave of the hand, however, much like the compatibilist purporting God fully controls creatures and yet they are free.

Panexperientialism does not relay on such hand waving. It affirms smooth emergentism, because experience - with its dual-aspect monism—is present all the way down to the smallest entities of existence. What emerges, therefore, are increasingly complex expressions of experience, with conscious experiences emerging only in the most complex creatures.

The mind-body advantage: It bears repeating that panexperientialism overcomes the Cartesian mind-body problem. Instead of separating mind from body by saying one is entirely mental and the other entirely physical, panexperientialism unites mind and body. It recognizes mentality and physicality as two dimensions of all existing beings. For more details, see our discussion above.

The other minds advantage: Philosophers have long realized the importance linked to each person thinking that others have minds something like their own. This »analogy of other minds « is crucial for communication, deep relationship, and moral responsibility. We cannot know with certainty other minds exist, of course, but there are powerful reasons to infer their existence. Our writing this essay is an exercise in such inference!

Panexperientialism allows us to infer the possibility of minds in human and some nonhuman animals. It thereby provides a conceptual framework for overcoming solipsism. And it helps us make far better sense of the activities, habits, motives, and expressions we experience in other creatures. This provides a conceptual basis for believing others are morally responsible in some ways similar to how we consider ourselves. It provides a conceptual basis for political engagement, scientific programs, and so much of what we take for granted in our lives. Reductive physicalist views provide no such basis.

The freedom and agency advantage: For a number of reasons, many have come to believe complex creatures - at least humans - have genuine but limited free will. This sense of freedom arises in nearly every human, because they sense it of their own experience. It appears that less complex creatures exert 
some measure of agency. Simple entities seem capable of self-organization. Even at the quantum level, a measure of indeterminacy seems present.

Panexperientialism makes sense of these degrees of freedom, agency, selforganization, and indeterminacy. It says no entity, from the smallest to the largest, is entirely controlled by external forces. Because self-causation occurs from the smallest forms, what we typically call full-blown (but limited) freedom is possible through smooth emergence. ${ }^{49}$ Panexperientialism provides a conceptual framework to talk about degrees of self-causation among creatures of varying complexity.

The problem of evil advantage: The logical problem of evil (theodicy) is essentially constituted of three propositions: 1 . An all-loving God would want to prevent genuine evil; 2. An all-powerful God would be capable of preventing genuine evil; 3. Genuine evils occur. Given these, one could conclude (a) an allloving and all-powerful God does not exist, (b) God exists but is not all-loving, (c) God exists but is not all-powerful, or (d) God exists, but genuine evils do not occur. ${ }^{50}$

Among these possibilities, we prefer option »c.« We believe God's power ought to be conceived in terms of uncontrolling love. This reconception retains the view that God is the most powerful being (almighty) without claiming God can singlehandedly control. A God incapable of such control is also not culpable for failing to prevent genuine evil.

The notion that God's love is inherently uncontrolling fits nicely in the panexperiential framework. If degrees of experiential self-causation are present in the most complex creatures to the least and if God cannot control creaturely self-causation, evil can occur that God cannot prevent. Panexperientialism also provides a framework of essential relationality, in which God feels the pain of all creation upon its occurring. God is the fellow sufferer who understands. ${ }^{51}$ An open and relational theist of the theocosmocentrist variety

49 We contend that freedom should always be understood as limited. At the very least, freedom is limited by space-time, history, and context. In so far as all agency is exerted by a particular physical entity in a particular place and time, in a particular historical, social, political context, the available possibilities that can be actualized at any given moment are limited. Hence, while freedom itself isn't necessarily constrained, the possibilities that can be freely actualized at any given moment are limited.

5o One might include the claim of mystery in addition to these four, but that isn't a solution to this problem.

$5^{1}$ Alfred North Whitehead famously called God the »fellow sufferer who understands« (Whitehead 1978 [1929]: 351). 
who adopts a panexperientialist perspective can affirm that all-loving God feels all pain but is not culpable for failing to prevent any of it.

The divine action advantage: Joining the dual-aspect monism of panexperientialism with the God-world relationship portrayed by theocosmocentrism offers a conceptual framework for identifying key features of divine action. Panexperientialism says God and all creatures are experiential. God and all creatures exhibit dual-aspect monism.

As a universal spirit, God has both a mental and physical aspect analogous to creaturely mental and physical aspects. The divine Spirit is similar to creaturely minds, in so far as both are not perceptible by our five senses but exert causal influence and receive causal influence. But Spirit differs from creaturely minds by being omnipresent, everlasting, and so on.

Just as our experiences are deeply shaped by the experiences of our bodies (at various levels), so too God's experiences are deeply shaped by creation. Just as the mind, with its physical and mental aspects, exerts influence on the body whose members also have physical and mental aspects, so the God with physical and spiritual aspects exerts influence on creation and creatures with physical and spiritual aspects.

Some call what we're describing the »World-Soul« analogy, »the world as God's body,« »God as the Mind of the Universe, « or »proprioception. «52 Charles Hartshorne, for instance, says God as the world's soul is analogous to the human mind's relation to the body. »Mind-body relation is not a oneto-one relation but a one-to-many relation, « says Hartshorne. »The body is a society of billions of cells, each a highly organized society of molecules and particles or wavicles. At a given moment, each of us, as a conscious individual, is a single reality; but our body is no such single realty.« Hartshorne then draws the analogy: "Similarly, God's cosmic body is a society of individuals, not a single individual.«53 Or as Dan Dombrowski puts it, »It makes sense to say both that the cosmos is ensouled and that God is embodied.«54

The »world is God's body« has important disanalogies, however. It does not mean the world is identical to God, which is pantheism. Saying God is the soul or mind of the universe-from the dual-aspect monism perspective-does not embrace Cartesian dualism, which says God is a wholly mental substance and the world comprised of wholly physical substances. Nor does it mean God

$5^{2}$ Among the many who think of the world as God's body, see McFague 2001. On proprioception, see Forrest 2016.

53 Hartshorne 1984: 59.

54 Dombrowski 1996: 86. 
as mind controls the world. ${ }^{55}$ And so on. Saying the world is God's body or God is the soul of the universe works if one assumes the truth of dual-aspect monism, panexperientialism, and theocosmocentrism.

The love advantage: As the authors of this essay, we are especially concerned with promoting overall well-being. In other words, we aim to love. We think adopting panexperientialism and theocosmocentrism helps us contribute to the common good. This relational worldview provides a metaphysical, epistemological, and ethical framework for living lives of love.

We are more likely to treat others and ourselves well, for instance, if we think we all have value and can experience value. We are more motivated to love God if we think our actions affect God's well-being. We are more likely to think it possible to »imitate God, as beloved children, and live lives of love « if we think God's being and our being have some similarities. We have no grounds for blaming God for evil, for instance, if a loving God cannot prevent evil singlehandedly. We can believe our lives and loves are ultimately significant if God always loves and cannot control us or creation. And so on.

\section{Conclusion}

One doesn't have to adopt theocosmocentrism or panexperientialism to be an open and relational theologian. However, we believe these views are especially congenial to the open and relational perspective. Both provide a foundation for understanding God and the world in a deeply relational way. We offer these ideas in the hope that some would find them valuable.

\section{References}

Augustine (2012) The Trinity V. 5. New York: New City Press.

Barbour, I. (1990) Religion in an Age of Science. San Francisco, CA: Harper \& Row.

Bracken, J. (2004) »Panentheism: A Field-Oriented Approach.« In: Clayton, P. and Peacocke, A. (eds.) In Whom We Live and Move and Have Our Being. Grand Rapids, MI: William B. Eerdmans.

Case-Winters, A. (1995) »Toward a Theology of Nature: Preliminary Intuitions.« Religiologiques 11, 249-267.

Chalmers, D.J. (1995) »Facing up to the Problem of Consciousness.« In: Journal of Consciousness Studies 2: 200-19.

55 Anna Case-Winters expresses this concern in Winters 1995: 249-267. 
Clayton, P. (2005) »Kenotic Trinitarian Panentheism.« Dialog, 44, 250-255.

Clayton, P. (2006) »Conceptual Foundations of Emergence Theory.« In: P. Clayton and P. Davies (eds.) The Re-Emergence of Emergence: The Emergentist Hypothesis from Science to Religion. Oxford: Oxford University Press, 1-31.

Clayton, P. (ed.) (2018) How I Found God in Everyone and Everywhere: An Anthology of Spiritual Memoirs. Monkfish.

Clayton, P. and Peacocke, A. (eds.) (2004) In Whom We Live and Move and Have our Being: Panentheistic Reflections on God's Presence in a Scientific World. Grand Rapids, Mich.: Eerdmans.

Cobb, J.B. and Griffin, D.R. (1976) Process Theology: An Introductory Exposition

Cooper, J.W. (2006) Panentheism: The Other God of the Philosophers-From Plato to the Present. Grand Rapids, MI: Baker Academic.

Davis, A. Clayton, P. (eds.) (2018) How I Found God in Everyone and Everywhere: An Anthology of Spiritual Memoirs. Monkfish.

Dombrowski, D.A. (1996) Analytic Theism, Hartshorne, and the Concept of God. New York, NY: SUNY Press.

Faber, R. (2014) The Divine Manifold. Lanham, MD: Lexington Books.

Faber, R. (2017) The Becoming of God. Eugene, OR: Wipf and Stock.

Forrest, P. (2016) »The Personal Pantheist Conception of God.«In: A.A. Buckareff and Y. Nagasawa (eds.) Alternative Concepts of God: Essays on the Metaphysics of the Divine. Oxford: Oxford University Press, 21-39.

Göcke, B.P. (2013) »Panentheism and Classical Theism.« Sophia, 52, 61-75.

Göcke, B.P. and Tapp, C. (eds.) (2018) The Infinity of God: Philosophical and Theological Perspectives. Indiana: The University of Notre Dame Press.

Griffin, D.R. (1997) »Panexperientialist Physicalism and the Mind-Body Problem.« Journal of Consciousness Studies 4(3), 248-268.

Griffin, D.R. (1998) Unsnarling the World-Knot: Consciousness, Freedom, and the Mind-Body Problem. University of California Press.

Hartshorne, C. (1967) »The Dipolar Conception of Deity.« Review of Metaphysics 21(2), $273-89$

Hartshorne, C. (1970) Creative Synthesis and Philosophic Method. London: SCM Press.

Hartshorne, C. (1984) Omnipotence and Other Theological Mistakes. Albany, N.Y.: State University of New York.

Henry, C.F.H. (1982) God, Revelation, and Authority: The God who Stands and Stays, Part One, vol. 5. Waco: Word, 304.

Jantzen, G. (1984) God's World, God's Body. Philadelphia, PA: Westminster.

Kim, J. (2005) Physicalism or Something near Enough. Princeton: Princeton University Press.

McFague, S. (2001) Life Abundant: Rethinking Theology and Economy for a Planet in Peril. Minneapolis: Fortress Press. 
Mesle. R.C. (1993) Process Theology: A Basic Introduction. St. Louis: Chalice.

Moltmann, J. (1993) The Trinity and the Kingdom. Philadelphia: Fortress.

Mullins, R.T. (2016 ) »The Difficulty with Demarcating Panentheism.« Sophia, 55, 325-346.

Oord, T.J (2004) Science of Love: The Wisdom of Well-Being. Philadelphia: Templeton Press.

Oord, T.J. (2010a) The Nature of Love: A Theology. St. Louis: Chalice.

Oord, T.J. (2010b) Defining Love:A Philosophical, Scientific, and Theological Engagement. Grand Rapids, Mich.: Brazos.

Peacocke, A. (1979) Creation and the World of Science. Oxford: Oxford University Press.

Peacocke, A. (2004) Theology for a Scientific Age. Oxford: Blackwell, 2004.

Peterson, G. (2001) »Whither Panentheism?« Zygon, 36, 395-405.

Pinnock, C.H. (2001) Most Moved Mover: A Theology of God's Openness. Grand Rapids, Mich.: Baker.

Pinnock, C.H. (2005) »Open Theism: An Answer to My Critics.«Dialog 44(3): 237-245.

Stephen Charnock (1853) »Discourse VI on the Immutability of God.«In The Existence and Attributes of God. Grand Rapids, MI: Baker Books, 1996.

Viney, D.W. (2007) »Hartshorne's Dipolar Theism and the Mystery of God.« Philosophia, 35, 341-350.

Ward, K. (2007) Divine Action: Examining God's Role in an Open and Emergent Universe. West Conshohocken. PA: Templeton Foundation.

Whitehead, A.N. (1978 [1929]) Process and Reality: An Essay in Cosmology, Corrected edition by D.R. Griffin and D.W. Sherburne. New York: Free Press.

Wynkoop M.B. (1972) A Theology of Love: The Dynamic of Wesleyanism. Kansas City, Mo.: Beacon Hill. 